\title{
Review of the Animal Law Conference, Sydney NSW - October 2019
}

\author{
Reem Lascelles \\ PhD Medical Physics, University of Hertfordshire. \\ Independent Researcher and Co-Founder of Ethical Vegan Earth Research Inc and EVER Sanctuary. \\ ORCID: https://orcid.org/0000-0002-5201-6114
}

Recommended citation. LASCELLES, R., Review of the Animal Law Conference, Sydney NSW October 2019, dA. Derecho Animal (Forum of Animal Law Studies) 10/4 (2019) - DOI https://doi.org/10.5565/rev/da.466

\section{Abstract}

A review of the Animal Law Conference in Sydney NSW hosted by the Young Lawyers Animal Law Committee Sydney.

Keywords: Animal Welfare Law, Sentience, Animal Welfare Education, Animal Law Conference.

Resumen - Reseña de la Conferencia sobre Derecho Animal, Sydney NSW (Australia) - Octubre 2019

Esta es la reseña de la Conferencia sobre Derecho Animal en Sídney, Nueva Gales del Sur (Australia) organizada por el Comité de Jóvenes abogados de Derecho Animal de Sídney.

Palabras clave: Derecho del Bienestar Animal, Educación sobre Bienestar animal, Conferencia de Derecho Animal.

On Saturday $12^{\text {th }}$ October, the NSW Young Lawyers Animal Law Committee ${ }^{1}$ held an Animal Law Conference entitled "Laws of Tomorrow" at the University of NSW, Sydney [\#AnimalLawConf19]. The Conference attracted approximately 150 attendees.

There were 6 speakers from across different political and legal spectrums. The following is a summary and link to each speaker

1. The Hon. Emma Hurst - Animal Justice Party $\mathrm{MP}^{2}$ and Tess Vickery, Policy Advisor to The Hon. Emma Hurst (panellist).

Emma spoke of her work within the Animal Justice Party (AJP) since her election into the NSW Legislative Council 6 months ago. She reported on the following main issues:

\footnotetext{
${ }^{1}$ NSW Young Lawyers Animal Law Committee https://www.facebook.com/nswyl.alc/ [accessed 16 Oct 2019].

${ }^{2}$ Emma Hurst MP https://www.facebook.com/EmmaHurstMP/ [accessed 16 Oct 2019]. 
- The Inquiry into Battery Hens in NSW, the State with the greatest number of Caged egg farms. The inquiry received approximately 12,000 submissions which were mostly opposed to battery cages. The Senate Report is underway.

- The second Inquiry, currently open for public submissions, is into the use of exotic animals in the entertainment sector which aims to end the use of exotic animals in entertainment and retire them to sanctuaries. There is currently one dolphinarium and one circus business using exotic animals left operating in NSW.

- The Animal Justice Party has been actively opposing the new Biosecurity Regulations and 'Right to Farm Bill' ${ }^{3}$ Under the new Biosecurity Regulations, farmers will be allowed to write their own criminal law. The 'Right to Farm' Bill provides special protection for farmers from nuisance lawsuits and increase trespass penalties to 3 years of imprisonment and fines up to $\$ 22,000$.

- Part of the Animal Justice Party's work is to legislate for animals of domestic violence. According to the AJP, 53\% of women fleeing domestic violence have reported their companion animals had also been abused. In addition, $33 \%$ of women delayed seeking refuge due to the concern for their companion animals. The AJP is pushing for government funding for domestic violence shelters to accommodate companion animals as well as have an animal abuse register.

2. Dr Meg Good, Animal Law \& Education Manager at Voiceless: the animal protection institute. ${ }^{4}$

Meg introduced Voiceless's new Animal Law Education (ALE) Program which produces one animal education resource suite per year known as the ALE Modules. Those modules are produced in collaboration with Bond University Centre for Professional Legal Education. The soon to be released module in 'Animal Law and Policy Reform' includes interviews with 10 animal law experts and animal protection advocates which will additionally be released as podcasts.

To learn more about these lessons and the upcoming Voiceless modules, you can ask to join the Voiceless Law Talk Facebook group at https://www.facebook.com/groups/VoicelessLawTalk/?ref=share

3. Shatha Hamade, Legal Counsel at Animals Australia. ${ }^{5}$

In addition to being the main Counsel for Animals Australia, Shatha is also their main undercover investigator of live exports in the Middle East. Recently representing Animals Australia in Jordan, Shatha has teamed up with Princess Alia of Jordan in an ambitious project to shut down zoos and stop the trafficking of exotic animals to the middle east.

Shatha highlighted the importance of Media campaigning strategic thinking and Political Lobbying within animal advocacy.

4. Dr Jed Goodfellow, Senior Policy Officer at RSPCA Australia. ${ }^{6}$

Jed explained what is termed 'The Iron Triangle of Agriculture Policy Community' in animal welfare which demonstrates the self-regulation of the $\mathrm{Ag}$ industry, reiterating the importance of establishing an Independent Office of Animal Welfare. The concept of the 'Iron Triangle of Ag Policy Community' places Animal Welfare in the vested interest of the Minister of Agriculture, the Department of Agriculture and the Peak Livestock Agricultural political organisations.

Jed spoke of the difficulties the RSPCA face in establishing new Standards and Guidelines to replace the old Model Codes of Practice in Agriculture. For example, introducing 'natural behaviour' as an essential component to hen welfare within the Standards giving hens better conditions was rejected by the Primary Industry representatives.

Jed also spoke of the new Act 'Inspector General of Live Animal Exports Bill 2019 ${ }^{7}$ which calls for an appointment of an Inspector General to oversee live exports.

5. Amanda Richman, Senior Lawyer at The Animal Law Institute. ${ }^{8}$

\footnotetext{
${ }^{3}$ Right to Farm Bill 2019 [NSW] https://legislation.nsw.gov.au/bills/af35492f-a4af-4a19-9178-4a3b2cd3e273 [accessed 16 Oct 2019].

${ }^{4}$ Voiceless the Animal Protection Institute https://www.voiceless.org.au/ [accessed 16 Oct 2019].

${ }^{5}$ Animals Australia https://www.animalsaustralia.org/ [accessed 16 Oct 2019].

${ }^{6}$ RSPCA Australia https://www.rspca.org.au/ [accessed 16 Oct 2019].

${ }^{7}$ Inspector-General of Live Animal Exports Bill 2019 (Cth)

https://www.aph.gov.au/Parliamentary_Business/Bills_Legislation/Bills_Search_Results/Result?bId=s1224 [accessed 16 Oct 2019].
} 
Amanda spoke of the work of the Animal Law Institute (ALI) in using Consumer Law as a strategy to challenge puppy farming and hold the industry accountable for veterinary fees in order to create incentives to shut down puppy mills.

As Animals are deemed as 'goods' under the Australian Consumer Law, the ALI have been bringing strategic litigation within Consumer Law. An example is Nala's Case. ${ }^{9}$ The ALI are currently looking to bring a case to Court rather than a tribunal to set a precedent for the future welfare of animals.

6. Tara Ward, Executive Director at Animal Defenders Office (ADO). ${ }^{10}$

Tara introduced the importance of Community Legal Centres and shared the difficulties the Animal Defenders Office have gone through trying to secure funding for a full-time paid solicitor. Tara shared the story of how the ADO started as a not for profit legal centre and the type of cases the ADO accepted ranging from defending animals to animal activists.

Tara also reminded the audience of the importance of the first recognition of 'Animal Sentience' in Australia within the ACT jurisdiction. The ACT now recognises in the law [Animal Welfare Legislation Amendment Bill 2019 (ACT) ${ }^{11}$ that animals are sentient and have Intrinsic Value. This law applies to all vertebrate species (including wildlife and fish) and cephalopods and some crustaceans.

A massive Thank you to the NSW Young Lawyers Animal Law committee for an inspirational day. For more information on the conference and speakers follow the NSW Young Lawyers Animal Law Committee on https://www.facebook.com/nswyl.alc/.

\footnotetext{
${ }^{8}$ The Animal Law Institute https://www.ali.org.au/ [accessed 16 Oct 2019].

${ }^{9}$ The Animal Law Institute: Our Work https://www.ali.org.au/our-work [accessed 16 Oct 2019].

${ }^{10}$ Animal Defenders Office https://www.ado.org.au/ [accessed 16 Oct 2019].

${ }^{11}$ The Animal Welfare Legislation Amendment Bill 2019 (ACT) https://www.legislation.act.gov.au/b/db_60107/?fbclid=IwAR0osJyjF2-vX9DveomU18cJS2Q0-PTA7I3vgYz6TQeAwUdea4mPvGssxo [accessed 16 Oct 2019]. 